\title{
Alternative method for quantification of alfa-amylase activity
}

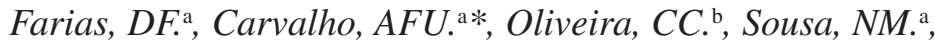 \\ Rocha-Bezerra, LCB. ${ }^{\mathrm{a}}$, Ferreira, PMP. ${ }^{\mathrm{c}}$, Lima, GPG. ${ }^{\mathrm{a}}$ and Hissa, DC. ${ }^{\mathrm{a}}$ \\ a Departamento de Biologia, Universidade Federal do Ceará - UFC, \\ Campus do Pici, CEP 60455-970, Fortaleza, CE, Brazil \\ 'Departamento de Farmacologia, Universidade Federal do Ceará - UFC, \\ Fortaleza, CE, Brazil \\ 'Campus Senador Helvídio Nunes de Barros, Universidade Federal do Piauí - UFPI, \\ CEP 64600-000, Picos, PI, Brazil \\ *e-mail: aurano@ufc.br \\ Received November 27, 2008 - Accepted February 26, 2009 - Distributed May 31, 2010
}

(With 2 figures)

\begin{abstract}
A modification of the sensitive agar diffusion method was developed for macro-scale determination of alfa-amylase. The proposed modifications lower costs with the utilisation of starch as substrate and agar as supporting medium. Thus, a standard curve was built using alfa-amylase solution from Aspergillus oryzae, with concentrations ranging from 2.4 to $7,500 \mathrm{U} \cdot \mathrm{mL}^{-1}$. Clear radial diffusion zones were measured after 4 hours of incubation at $2{ }^{\circ} \mathrm{C}$. A linear relationship between the logarithm of enzyme activities and the area of clear zones was obtained. The method was validated by testing $\alpha$-amylase from barley at the concentrations of 2.4; $60 ; 300$ and $1,500 \mathrm{U}^{-\mathrm{mL}^{-1}}$. The proposed method turned out to be simpler, faster, less expensive and able to determine on a macro-scale $\alpha$-amylase over a wide range (2.4 to 7,500 U.mL $\left.\mathrm{mL}^{-1}\right)$ in scientific investigation as well as in teaching laboratory activities.
\end{abstract}

Keywords: alfa-amylase, alternative method, quantification.

\section{Alternativa para quantificação de alfa-amilase}

\begin{abstract}
Resumo
Modificações foram propostas ao método sensível de difusão em ágar para a macrodeterminação de alfa-amilase. As modificações propostas diminuem os custos, com a utilização de amido como substrato e ágar como meio solidificante. Assim, foi construída uma curva padrão utilizando uma solução de alfa-amilase de Aspergillus oryzae com concentrações variando de 2,4 a $7.500 \mathrm{U} \cdot \mathrm{mL}^{-1}$. Em seguida, as zonas claras de difusão radial foram mensuradas depois de 4 horas de incubação a $20^{\circ} \mathrm{C}$. Foi obtida uma relação linear entre o logaritmo da atividade enzimática e os diâmetros das zonas claras. $\mathrm{O}$ método foi validado utilizando-se soluções de alfa-amilase de cevada nas concentrações de 2,4; 60; 300 e 1.500 U.mL ${ }^{-1}$. O método tornou-se mais simples, rápido, com baixo custo e passível de ser utilizado para macrodeterminação de alfa-amilase em ampla faixa $\left(2,4\right.$ a $\left.7.500 \mathrm{U} \cdot \mathrm{mL}^{-1}\right)$ na investigação científica e para fins didáticos em aulas práticas.
\end{abstract}

Palavras-chave: alfa-amilase, método alternativo, quantificação.

\section{Introduction}

In the early eighties, Tauschel and Rudolph (1982) proposed a new radial diffusion method for the determination on a micro-scale of $\alpha$-amylase activity in serum, urine and organic extracts as an alternative and/ or replacement of spectrophotometric methods used in those days. Among the several advantages, the proposed method was able to quantify the enzyme activity in a concentration-dependent way with excellent linearity and reliability over an extended concentration range (1-1100 $\left.\mathrm{mU} \cdot \mathrm{mL}^{-1}\right)$, correlating concentration with the area of diffusion zones. These advantages were achieved through the utilisation of expensive chemical reagents making it inadequate for teaching purposes or even for scientific research dealing with a large number of samples, mainly when high sensitivity is not needed.

The utilisation of the radial diffusion method in solid support to quantify amylase activity with cheaper reagents had already been proposed forty years ago by Mestecky et al. (1969). They had used agar as supporting medium and starch as amylase substrate, the amy- 
loclastic activity being revealed by lugol. Nevertheless, the method was useful only for macrodetermination over a narrow range of activity ( 25 to $750 \mathrm{U} \cdot \mathrm{mL}^{-1}$ ) and these components continued to be used for a long time only for qualitative detection (Hankin and Anagnostakis, 1975).

The present study proposed modifications to the method of $\alpha$-amylase quantification developed by Tauschel and Rudolph (1982) as an attempt to reduce costs and improve simplicity over a wide range of amylase activity.

\section{Material and Methods}

\subsection{Reagents}

Soluble starch (VETEC, Rio de Janeiro, Brazil) was used as enzymatic substrate; agar-agar (VETEC, Rio de Janeiro, Brazil) was used for medium solidification; $\alpha$-amylase from Aspergillus oryzae (Ahlburg) Cohn (EC 3.2.1.1, Sigma-Aldrich Co., USA) was used to produce a standard curve in order to represent the relation between enzymatic concentration and the area of clear radial diffusion zones; $\alpha$-amylase from barley (EC 3.2.1.1., Sigma-Aldrich Co., USA) was used to validate the method and lugol solution (VETEC, Rio de Janeiro, Brazil) was used to reveal the clear zones through complex iodine-starch formation.

\subsection{Experimental procedures}

A stock solution was prepared with $0.1786 \mathrm{~g}$ of $\alpha$-amylase from Aspergillus oryzae in $1 \mathrm{~mL}$ of $20 \mathrm{mM}$ fosfate buffer with $6 \mathrm{mM} \mathrm{NaCl}, \mathrm{pH} 6.9$ (Bergmeyer, 1974) (loading buffer). This solution (7,500 U.mL $\left.{ }^{-1}\right)$ was serially five-fold diluted up to $2.4 \mathrm{U} \cdot \mathrm{mL}^{-1}$.

For establishing the ideal agar concentration, at constant starch concentration $\left(0.01\right.$ g.mL $\left.\mathrm{mL}^{-1}\right)$, four agarstarch plates containing loading buffer in increasing agar concentration $\left(0.005\right.$ g. $\mathrm{mL}^{-1} ; 0.01$ g.mL $\mathrm{mL}^{-1} ; 0.02$ g.mL ${ }^{-1}$ and 0.04 g. $\mathrm{mL}^{-1}$ ) were prepared. To each plate, $20 \mu \mathrm{L}$ of the most and the +least concentrated $\alpha$-amylase solutions (7,500 and 2.4 U. $\mathrm{mL}^{-1}$, respectively) were added, leading to the formation of clear diffusion zones after 4 hours of incubation at $20{ }^{\circ} \mathrm{C}$. Likewise, for establishing the ideal starch concentration, at constant agar concentration $\left(0.02 \mathrm{~g} . \mathrm{mL}^{-1}\right)$, the same procedure was done with increasing starch concentration $\left(0.0025 \mathrm{~g} \cdot \mathrm{mL}^{-1}\right.$; 0.005 g.mL ${ }^{-1} ; 0.01$ g.mL ${ }^{-1} ; 0.02$ g.mL $\mathrm{mL}^{-1} ; 0.04$ g.mL $\left.{ }^{-1}\right)$.

Following the determination of the ideal concentrations of agar and starch, the supporting medium for enzymatic activity assay was prepared with $0.5 \mathrm{~g}$ of starch and $1.0 \mathrm{~g}$ of agar dissolved in $50 \mathrm{~mL}$ of loading buffer.

Thirty-six plates containing $25 \mathrm{~mL}$ of agar-starch were prepared as described above. To each plate, $20 \mu \mathrm{L}$ of the highest and the lowest concentration of $\alpha$-amylase solutions $\left(7,500\right.$ and $\left.2.4 \mathrm{U} \cdot \mathrm{mL}^{-1}\right)$ were innoculated, leading to the formation of clear diffusion zones after 4 hours of incubation at $20^{\circ} \mathrm{C}$. Three plates per hour were treated with lugol solution to verify the reliability and reproducibility of the clear zones resulting from the enzymatic activity.
Fifty millilitres of agar-starch were prepared as described before and transferred to a plate. Six wells were made on the gel and $20 \mu \mathrm{L}$ of each solution of $\alpha$-amylase was innoculated to each one. The plates were incubated for 4 hours at $20{ }^{\circ} \mathrm{C}$. Ten replicates were run to analyse the accuracy and reproducibility of the curve, using oneway analysis of variance (ANOVA, $\alpha=0.01$ ) followed by Newman-Keuls test $(\mathrm{P}<0.01)$ (GraphPad program, Intuitive Software for Science, San Diego, CA).

Plates were stained with lugol solution to show the clear zones to be measured in two perpendicular directions using a paquimeter. The total area of enzyme diffusion and action was calculated in $\mathrm{cm}^{2}$. It is important to emphasise that the well areas were excluded from the measurements.

For validating the method, ten plates containing $50 \mathrm{~mL}$ of agar-starch were prepared as described above and diluted enzyme solutions were added to the wells. A purified $\alpha$-amylase from barley (EC 3.2.1.1., SigmaAldrich Co., St Louis, USA) was used as the validation enzyme, which was previously prepared following the same conditions described previously. The area of the clear zones produced by solutions at $2.4 ; 60 ; 300$; 1,500 U.mL ${ }^{-1}$ was compared to that produced by the standard enzyme at the same concentrations and after the same incubation conditions.

\subsection{Statistical analyses}

In order to determine differences between clear zones areas, data (means \pm standard deviation) were compared by one-way analysis of variance (ANOVA) followed by Newman-Keuls tests $(\mathrm{P}<0.05)$ using the GraphPad program (Intuitive Software for Science, San Diego, CA). Variancy coefficient, Spearman correlation coefficient, ANOVA, Kolmogorov-Smirnov and $t$-student were utilised to analyse reproducibility and reliability of the methodology.

\section{Results and Discussion}

The proposed method to quantify $\alpha$-amylase showed to be effective. The starch on the plate was hydrolysed by $\alpha$-amylase and the hydrolysis products diffused through the medium. After the staining process, lugol produced clear areas around the wells containing the enzyme while the rest of the starch-containing agar medium showed the characteristic blue black colour due to complex iodinestarch formation. A similar reaction appears to occur in the Tauschel and Rudolph method, when enzyme hydrolyzes Reactone Red 2 B-amylopectin, leading to clear zones formation. In both methods, clear zones depend on enzimatic concentration.

The increase in agar concentration led to decrease in clear zone area. In fact, agar might represent a physical barrier for enzyme migration. Based on these observations it is suggested that $0.02 \mathrm{~g} \cdot \mathrm{mL}^{-1}$ would be the ideal agar concentration, since it could provide adequate consistency of the medium and it was not characterised as an 


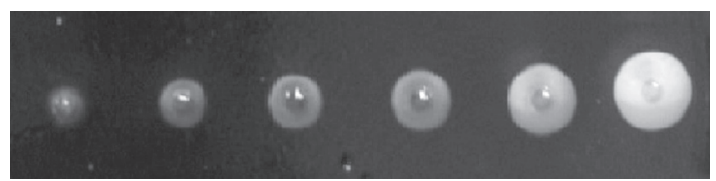

Figure 1. Enzymatic degradation halos (clear zones) corresponding to increasing enzymatic concentrations $(2.4 ; 12$; $60 ; 300 ; 1,500$ and 7,500 U.mL ${ }^{-1}$ ).

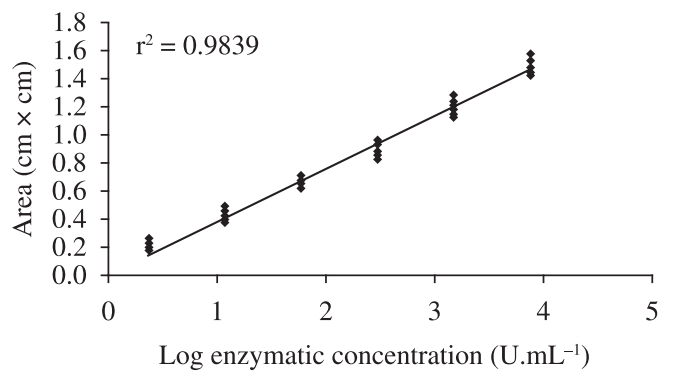

Figure 2. Standard curve. Linear relationship between the logarithmic of enzymatic concentration and the enzymatic degradation halos.

obstacle to an adequate clear zone formation. Similarly, it was also observed that when starch concentration increases, clear zone size decreases. This could be explained by the fact that the enzyme reaches its saturation point rapidly when substrate is present in high concentration, leading to a smaller enzymatic activity zone (Voet and Voet, 2004). Starch concentration of 0.01 g. $\mathrm{mL}^{-1}$ was selected to provide a satisfactory measurement.

The shortest time required for a satisfactory measurement, both for the highest $\left(7,500 \mathrm{U} \cdot \mathrm{mL}^{-1}\right)$ and the lowest (2.4 U.mL $\left.\mathrm{mL}^{-1}\right)$ concentration of enzyme solutions was 4 hours. Such incubation time is comparable to that of the Tauschel and Rudolph method which is performed between 3 and 6 hours.

The obtained standard curve as well as that demonstrated by Tauschel and Rudolph (1982) revealed to be reliable and highly reproducible, confirmed by variation analysis (ANOVA; $p=0.9998$ ). The enzymatic activity zones according to decreasing concentrations of Aspergillus oryzae $\alpha$-amylase are shown in Figure 1. The curve demonstrated in Figure 2 showed that the clear zones were directly proportional to the logarithm of enzyme concentration (U.mL ${ }^{-1}$ ) and presents a wide range linearity zone, not being necessary sample dilutions. Hence, procedure errors might be prevented. However, it is difficult to explain why Mestecky et al. (1969) had reported that amyloclastic starch methods with the formation of a blue iodine complex are not linear over the whole tested range (25-750 U.mL ${ }^{-1}$ ). In the present work a wider range was used (2.4-7,500 U.mL ${ }^{-1}$ ) and even so the linearity could be observed. The high determination coefficient confirms the high correlation between the variables $\left(r^{2}=0.9839\right)$. The high Spearman coefficient obtained $(r=0.9919)$ also confirms that the data are highly related. The regression analysis is represented by the equation $\mathrm{y}=0.3777 \mathrm{x}$.

The degradation clear zone areas $(0.10 \pm 0.02 ; 0.65 \pm$ $0.03 ; 0.76 \pm 0.10$ and $1.05 \pm 0.06 \mathrm{~cm}^{2}$ ) formed by standard $\alpha$-amylase hydrolysis at four different concentrations revealed to be statistically similar $(\mathrm{p}>0.01)$ to the ones produced by validation $\alpha$-amylase $(0.14 \pm 0.01 ; 0.59 \pm$ $0.02 ; 0.66 \pm 0.04$ and $\left.0.87 \pm 0.15 \mathrm{~cm}^{2}\right)$ when compared at the same concentrations $\left(2.4 ; 60 ; 300\right.$ and $1,500 \mathrm{U}_{\mathrm{mL}}^{-1}$, respectively), showing that the method is valid and viable for the macro scale determination of $\alpha$-amylase.

\section{Conclusion}

The proposed method turned out to be simpler, faster, less expensive and able to determine on a macro-scale $\alpha$-amylase over a wide range in scientific investigation as well as in teaching laboratory activities.

\section{References}

BERGMEYER, HU., 1974. Methods of enzymatic analysis. 2 ed. New York: Academic Press.

HANKIN, L. and ANAGNOSTAKIS, SL., 1975.The use of solid media for detection of enzyme production by fungi. Mycologia, vol. 67 , p. 597-607.

MESTECKY, J., KRAUS, FW., HURST, DC. and VOIGHT, AS., 1969. A simple quantitative method for -amylase determinations. Analytical Biochemistry, 1969, vol. 30, no. 2, p. 190-198.

TAUSCHEL, HD. and RUDOLPH, C., 1982. A new sensitive radial diffusion method for microdetermination of alphaamylase. Analytical Biochemistry, vol. 120, no. 2, p. 262-266.

VOET, D. and VOET, JG., 2004. Biochemistry. 3 ed. Hoboken: John Wiley \& Sons. 
